\title{
EFFECT OF ETHANOLIC FRUITS EXTRACT OF EMBELIA RIBES BURM ON DEXAMETHASONE INDUCED INSULIN RESISTANCE IN MICE
}

\author{
Available online at www.ijistweb.com \\ RESEARCH ARTICLE \\ ${ }^{1}$ Garg Naveen*, ${ }^{2}$ Mathur Prashant, ${ }^{3}$ Saraswat Rohit, ${ }^{3}$ Sharma Chandrachud \\ ${ }^{1}$ Dept. of Pharmacology and Pharmacotherapeutics, Jawaharlal Nehru Medical College, K. L. E. \\ University, Belgaum, Karnataka, India. \\ ${ }^{2}$ Department of Pharmacy Practice, SGRRITS, Dehradoon, India. \\ ${ }^{3}$ Department of Pharmacy, Rajasthan Pharmacy College, Bhankrota, Jaipur (Raj.) India. \\ *Corresponding Author's E-mail: naveen.pharmec@gmail.com
}

\begin{abstract}
This study was designed to examine the effect of ethanolic fruits extract of Embelia ribes Burm on dexamethasone$(1 \mathrm{mg} / \mathrm{kg}$, intramuscular, 22 days) induced Insulin resistance in Mice. Twenty two days of oral feeding the extract $(100 \mathrm{mg} / \mathrm{kg}$ and $200 \mathrm{mg} / \mathrm{kg})$ to induced mice resulted in significant $(P<.01)$ decrease in blood glucose, triglyeride, Insulin, HOMA-IR index and increase in body weight levels as compared to dexa control mice. Further, the extract also significantly $(P<.01)$ decreased the MDA levels and significantly $(P<.01)$ increased the superoxide dismutase, catalase, and glutathione levels as compared to above levels in Hepatic tissue of dexa control mice and also increased glucose uptake by skeletal muscle. The results of test drug were comparable to pioglitazone ( $2 \mathrm{mg} / \mathrm{kg}, \mathrm{i} . \mathrm{m}, 22 \mathrm{days})$, a standard antihyperglycemic agent.
\end{abstract}

The study concludes that Embelia ribes enhances the antioxidant defense against reactive oxygen species produced under hyperglycemic condition and Embelia ribes may prove to be effective in the treatment of Type-II Diabetes mellitus owing to its ability to decrease insulin resistance.

Keywords: Diabetes, Hyperinsulinemia, NIDDM, insulin resistance.

\section{INTRODUCTION}

Diabetes is the world's largest endocrine disorder with dearranged carbohydrate, fat and protein metabolism.(1) It is estimated that by the year 2020 there will be approximately 250 million people affected by type 2 diabetes mellitus worldwide.(2) Although the primary factors causing this disease are unknown, it is clear that insulin resistance plays a major role in its development. Evidence for this comes from (a) the presence of insulin resistance 10-20 years before the onset of the disease $(3,4)$ (b) crosssectional studies demonstrating that insulin resistance is a consistent finding in patients with type 2 diabetes $(4,5)$; and (c) prospective studies demonstrating that insulin resistance is the best predictor of whether or not an individual will later become diabetic. $(3,4)$ Thus interventions to decrease insulin resistance may postpone development of Type-ll Diabetes and its complications.(6)
Insulin resistance (IR) is the condition in which normal amounts of insulin are inadequate to produce a normal response in fat, muscle and liver cells.(2) Lipid accumulation within myocytes and hepatocytes is strongly associated with insulin resistance in diabetics. (5) it is also defined as a defect in the ability of insulin to stimulate glucose uptake and result in metabolic syndrome characterized by impaired glucose tolerance and hyperinsulinemia.

Hyperinsulinemia is a central pathphysiological feature of non-insulin dependent diabetes mellitus (NIDDM) the co-existence of insulin resistance and hyperinsulinemia appear to contribute directly or indirectly to many other disorders, such as impaired glucose tolerance, dyslipidemia, hypertension, oxidative stress, endothelial dysfunction, atherosclerosis and coronary heart disease which together are responsible for substantial morbidity and premature mortality. 
The combination of increased insulin resistance an inadequate insulin secretion in response to a glucose challenge will result in hyperglycemia. High blood glucose levels promote autooxidation of glucose to form free radicals. The generation of free radical $s$ beyond the scavenging abilities of endogenous antioxidant defense, a condition known as oxidative stress, can result in macro and microvascular dysfunction and polyneuropathy, therefore oxidative stress resulting from hyperglycemia and insulin resistance can worsen NIDDM by promoting further insulin resistance and decreased insulin secretion.

Embelia Ribes Burm (Myrisiancae) commonly known as Vidanga, Bavding (Gujrati) and False Black Pepper in English is a large woody climbing shrub and is widely distributed throughout in India. It is esteemed in Ayurveda as a powerful anthelmintic. Ayurveda also describes vidanga as a pungent and cures flatulence and colic. whole plant is used as antiinflammatory drug to relieve Rheumatism and Fever. One Ayurvedic formulation, vidangadya churna (powder of vidanga), containing vidanga as main ingredient is taken with honey to alleviate obesity, (7) In a preliminary study, Tripathi et al, (8) has reported the Antihyperglycemic activity of decoction of Embelia Ribes fruit in glucose fed albino rabbits. Recently, Bhandari et al (9) have reported Antihyperglycemic effect of Aqueous extract of Embelia ribes in Streptozocin induced in diabetic rats, .Embelia Ribes markedly improved the Dyslipidemia in glucose diabetic rats (9) and no study has been reported on effect of ethanolic fruits extract of Embelia Ribes on dexamethasone induced insulin resistance.

Taking into consideration of the reported activities the present study is planned to investigate the effect of ethanolic fruits extract of Embelia ribes on Dexamethasone induced Insulin Resistance.

\section{MATERIALS AND METHOD}

\section{Plant material and preparation of extract:}

The fresh dried fruits are collected from local market in Belgaum, Karnataka. The specimen was authenticated by botanical department of RLS institute in botanical department Belgaum.
The fruits were extracted with $90 \%$ ethanol in a soxhlet apparatus for 72 hours. The solvent was removed under reduced pressure to give a dry extract, $7 \%$ yield $w / w$ (with respect to the crude material) and dose equivalent to $200 \mathrm{mg}$ of the crude drug per kilogram body weight was calculated, and suspended in $2 \% \mathrm{v} / \mathrm{v}$ Tween 80 solution for the experiment.

\section{Animals}

48 Albino mice weighing 25-30 g were used for study and were kept in animal house at $26 \pm 2 \circ \mathrm{C}$ with relative humidity $44-56 \%$ along with light and dark cycles of $12 \mathrm{~h}$. Institution Animal Ethics Committee has approved the experimental protocol (627/02/a/CPCSEA). Animals were provided with standard diet and water ad libitum. The food was withdrawn 18-24 h before the start of the experiment.

\section{Experimental design}

Dexamethasone-induced insulin resistance in mice) (6)

All the mice were weighed before treatment, group I (normal control) received equivalent amount of $1 \%$ gum acacia ( $1 \mathrm{ml} / \mathrm{kg}$,p.o.), and 30 mice were rendered hyperglycemic by daily administration of a prestandardised dose of dexamethasone ( $1 \mathrm{mg} / \mathrm{kg}$, i.m.) for consecutive 7 days and then divided in to five groups of six each. Group II (DEXA control) continued to receive only dexamethasone and $1 \%$ gumacacia (1 $\mathrm{ml} / \mathrm{kg}$, p.o.) for next 15 days, III received Pioglitazone (2 mg/kg, p.o.) along with dexamethasone respectively for 15 days. Groups $\mathrm{V}$, VI were treated with dexamethasone along with two different doses of ER $100,200 \mathrm{mg} / \mathrm{kg}$, p.o. respectively for 15 days. Simultaneously four other groups (groups VII, VIII) each with six normoglycemic animals, were administered equivalent amount of Pioglitazone and two different doses of ER 100, and $200 \mathrm{mg} / \mathrm{kg}$, p.o. respectively (Table 1). On the last day, after overnight fasting, all the animals were weighed and later sacrificed by cervical dislocation. Blood samples were collected and used for estimation of glucose and triglyceride. Biochemical estimation of plasma glucose and serum triglyceride and was done by GPO/POD method respectively using standard diagnostic 
kits from ERBA India Ltd., and serum insulin RIA method by france.

Table 1: Effect of Embelia ribes burm. on plasma glucose, serum triglyceride level, serum insulin body weight and HOMA-IR index in dexamethasone-induced insulin resistance.

\begin{tabular}{|c|c|c|c|c|c|c|}
\hline $\begin{array}{l}\text { Sr. } \\
\text { No. }\end{array}$ & Groups & $\begin{array}{l}\text { Plasma } \\
\text { Glucose } \\
(\mathrm{mg} / \mathrm{dl}) \\
\end{array}$ & $\begin{array}{c}\text { Serum } \\
\text { triglyceride } \\
\text { (mg/dl) } \\
\end{array}$ & $\begin{array}{c}\text { Insulin } \\
(\mathbf{u} \text { IU/ml) }\end{array}$ & $\begin{array}{c}\text { Body weight } \\
\text { (gm) }\end{array}$ & $\begin{array}{l}\text { HOMA- IR } \\
\text { index }\end{array}$ \\
\hline 1 & $\begin{array}{l}\text { Normal } \\
\text { control }\end{array}$ & $58.68 \pm 0.38$ & $82.73 \pm 4.9$ & $0.7333 \pm 0.03$ & $0.4167 \pm 0.30$ & $0.1065 \pm 0.005$ \\
\hline 2 & Dexa. Control & $\begin{array}{l}79.35 \pm \\
3.08^{\mathrm{a}^{* * *}} \\
\end{array}$ & $149.6 \pm 6.7^{\mathrm{a}^{* *}}$ & $19.50 \pm 1.7^{\mathrm{a}^{* * *}}$ & $6.500 \pm 0.46^{\mathrm{a}^{* *}}$ & $3.874 \pm 0.4^{\mathrm{a}^{* * *}}$ \\
\hline 3 & $\begin{array}{l}\text { Dexa. } \\
\text { Standard }\end{array}$ & $\begin{array}{l}60.77 \pm \\
0.85^{b^{* * *}}\end{array}$ & $90.76 \pm 1.3^{\mathrm{b}^{* * *}}$ & $0.4500 \pm 0.056^{\mathrm{b}^{* *}}$ & $4.167 \pm 0.16^{b^{* *}}$ & $0.06748 \pm 0.008^{\mathrm{b}^{* *}}$ \\
\hline 4 & $\begin{array}{l}\text { Dexa.+ } \\
\text { E.Ribes } 100\end{array}$ & $\begin{array}{l}67.83 \pm \\
1.21^{\mathrm{a}^{* * *}} \\
\end{array}$ & $121.1 \pm 7.2^{\mathrm{a}^{* *}}$ & $0.9167 \pm 0.03^{\mathrm{a}^{* *}}$ & $2.667 \pm 0.61^{\mathrm{a}^{* *}}$ & $0.1538 \pm 0.007^{\mathrm{a}^{* *}}$ \\
\hline 5 & $\begin{array}{l}\text { Dexa+ } \\
\text { E.Ribes } 200\end{array}$ & $\begin{array}{l}61.90 \\
\pm 2.34^{b^{* *}}\end{array}$ & $108.0 \pm 7.2^{b^{* *}}$ & $0.9167 \pm 0.04^{b^{* * *}}$ & $3.833 \pm 0.47^{b^{* *}}$ & $0.1411 \pm 0.01^{\mathrm{b}^{* * *}}$ \\
\hline 6 & $\begin{array}{l}\text { Norm. } \\
\text { Standard }\end{array}$ & $58.90 \pm 1.71$ & $84.75 \pm 8.5$ & $0.4833 \pm 0.03$ & $0.3333 \pm 0.47$ & $0.0701 \pm 0.004$ \\
\hline 7 & $\begin{array}{l}\text { Norm. } \\
\text { E.Ribes } 100\end{array}$ & $55.79 \pm 1.16$ & $92.05 \pm 1.1$ & $0.9167 \pm 0.02$ & $2.333 \pm 0.49$ & $0.1262 \pm 0.004$ \\
\hline 8 & $\begin{array}{l}\text { Norm }+ \\
\text { E.Ribes } 200\end{array}$ & $51.13 \pm 0.58$ & $90.60 \pm 9.5$ & $1.583 \pm 0.11$ & $2.833 \pm 0.94$ & $0.2002 \pm 0.01$ \\
\hline
\end{tabular}

Values are expressed as mean \pm S.E.M., $n=6$, DEXA $=$ dexamethasone $1 \mathrm{mg} / \mathrm{kg}$, i.m., PIO = Pioglitazone $2 \mathrm{mg} / \mathrm{kg}$, p.o., ER= Embelia ribes 100, 200mg/kg, p.o.

$\mathrm{a}^{*} p<0.05, \mathrm{a}^{* *} p<0.01$ when compared with normal control.

$\mathrm{b}^{* *} p<0.01$ when compared with DEXA-control.

$(+)$ and $(-)$ sign indicates increase and decrease in body weight.

\section{Hepatic antioxidant enzymes assay (10-13)}

Liver samples were dissected out and washed immediately with ice cold saline to remove as much blood as possible. Liver homogenates $(5 \%, \mathrm{w} / \mathrm{v})$ were prepared in cold $50 \mathrm{mM}$ Tris buffer ( $\mathrm{pH}$ 7.4) using Remi homogenizer. The unbroken cells and cell debris were removed by centrifugation at 5000rpm for 10 minusing a Remi refrigerated centrifuge. The supernatant was used for the estimation of GSH (Ellaman, 1959), malondialdehyde (MDA) (Ohkawa et al 1979), superoxide dismutase (SOD) (nandi \& chatterjee) and catalase (sinha et al 1972) levels (Table 2).

Table 2: Effect of Embelia ribes Burm. on different antioxidant defence levels

\begin{tabular}{|l|l|l|l|l|l|}
\hline $\begin{array}{l}\text { Sr. } \\
\text { No. }\end{array}$ & \multicolumn{1}{|c|}{ Groups } & $\begin{array}{c}\text { MDA (ug/g } \\
\text { of tissue) }\end{array}$ & $\begin{array}{c}\text { GSH (ug/g of } \\
\text { tissue) }\end{array}$ & SOD(unit/ml) & $\begin{array}{c}\text { CAT (uM of } \mathbf{H}_{2} \mathbf{O}_{2} \\
\text { /g of tissue/min) }\end{array}$ \\
\hline 1 & Normal control & $14.63 \pm 1.0$ & $31.49 \pm 0.48$ & $76.42 \pm 5.2$ & $0.8600 \pm 0.01$ \\
\hline 2 & Dexa. Control & $24.25 \pm 1.8^{\mathrm{a}^{* * *}}$ & $19.48 \pm 0.43^{\mathrm{a}^{* *}}$ & $26.00 \pm 0.6^{\mathrm{a}^{* *}}$ & $0.6633 \pm 0.01^{\mathrm{a}^{* *}}$ \\
\hline 3 & Dexa. Standard & $14.73 \pm 1.0^{\mathrm{b}^{* *}}$ & $25.93 \pm 0.77^{\mathrm{b}^{* * *}}$ & $70.61 \pm 3.4^{\mathrm{b}^{* *}}$ & $0.8100 \pm 0.01^{\mathrm{b}^{* *}}$ \\
\hline 4 & Dexa.+ E.Ribes 100 & $21.15 \pm 1.3$ & $21.35 \pm 0.88$ & $60.49 \pm 0.88^{\mathrm{b}^{* *}}$ & $0.7217 \pm 0.003^{\mathrm{b}^{*}}$ \\
\hline 5 & Dexa.+ E.Ribes 200 & $18.59 \pm 1.2^{\mathrm{b}^{*}}$ & $24.61 \pm 0.69^{\mathrm{b}^{*}}$ & $71.97 \pm 0.90^{\mathrm{b}^{* *}}$ & $0.7550 \pm 0.01^{\mathrm{b}^{* * *}}$ \\
\hline 6 & Norm. Standard & $14.74 \pm 1.2$ & $30.53 \pm 1.05$ & $69.49 \pm 4.7$ & $0.8283 \pm 0.02$ \\
\hline 7 & Norm.+ E.Ribes 100 & $14.10 \pm 1.1$ & $30.62 \pm 1.18$ & $72.72 \pm 4.6$ & $0.8667 \pm 0.01$ \\
\hline 8 & Norm+ E.Ribes 200 & $13.46 \pm 0.9$ & $29.24 \pm 2.739$ & $76.38 \pm 4.0$ & $0.8467 \pm 0.01$ \\
\hline
\end{tabular}


Values are expressed as mean \pm S.E.M., $n=6$, DEXA $=$ dexamethasone $1 \mathrm{mg} / \mathrm{kg}$, i.m., PIO = Pioglitazone $2 \mathrm{mg} / \mathrm{kg}$, p.o., ER = Embelia ribes 100, $200 \mathrm{mg} / \mathrm{kg}$, p.o.

$\mathrm{a}^{* *} p<0.01$ when compared with normal control.

$\mathrm{b}^{*} p<0.05, \mathrm{~b}^{* *} p<0.01$ when compared with DEXA-control.

\section{Effect on glucose uptake in isolated mice hemidiaphragm (14-16)}

Glucose uptake in mice hemidiaphragm was estimated by the method described by with some modification. (14) Ten sets, containing graduated test tubes $(n=6)$ each, were used for study of non-insulin assisted and insulin assisted glucose uptake. The diaphragms were taken out quickly avoiding traumas and divided into two halves. The hemidiaphragms were rinsed in cold Tyrode solution (without glucose) to remove any blood clots. In non-insulin assisted glucose uptake study, one hemidiaphragm of each animal from groups I to VI was exposed to $2 \mathrm{ml}$ Tyrode solution with glucose $(2000 \mathrm{mg} / \mathrm{l})$ in respective graduated test tubes. In insulin assisted glucose uptake study, the remaining hemidiaphragm of each animal from groups I to VI was exposed to $2 \mathrm{ml}$ Tyrode solution with glucose $(2000 \mathrm{mg} / \mathrm{l})+$ insulin $(0.25 \mathrm{IU} / \mathrm{ml})$ in respective graduated test tubes. All the graduated test tubes were incubated for $30 \mathrm{~min}$ at $37^{\circ} \mathrm{C}$ in an atmosphere of $95 \% \mathrm{O} 2-5 \% \mathrm{CO}_{2}$ with shaking at 140 cycles per minutes. Following incubation, the hemidiaphragm was taken out and weighed. The glucose content of the incubated medium was measured by GOD/POD, enzymatic method. Glucose uptake was calculated as the difference between the initial and final glucose content in the incubation medium (Table 3)

Table 3: Effect of Tectona grandis Linn. on glucose uptake in mice isolated hemidiaphragm.

\begin{tabular}{|c|l|l|l|}
\hline Sr. no. & \multicolumn{1}{|c|}{ Group } & $\begin{array}{c}\text { Non-insulin assisted glucose } \\
\text { uptake } \mathbf{~ m g / g / 3 0 ~} \mathbf{~ m i n}\end{array}$ & $\begin{array}{c}\text { Insulin assisted glucose uptake } \\
\mathbf{~ m g / g / 3 0 ~} \mathbf{~ m i n}\end{array}$ \\
\hline I. & Normal & $9.365 \pm 0.49$ & $15.38 \pm 1.3$ \\
\hline II. & DEXA-control & $6.077 \pm 0.36^{\mathrm{a}^{* *}}$ & $9.320 \pm 0.61^{\mathrm{a}^{* *}}$ \\
\hline III. & DEXA+ PIO & $8.798 \pm 0.27$ & $20.24 \pm 0.93^{\mathrm{c}^{* *}}$ \\
\hline IV. & DEXA+ ER-100 & $11.24 \pm 0.30^{\mathrm{b}^{* *}}$ & $14.04 \pm 0.57^{\mathrm{c}^{* *}}$ \\
\hline V. & DEXA+ ER-200 & $13.05 \pm 1.05^{\mathrm{b}^{* *}}$ & $18.14 \pm 0.91^{\mathrm{c}^{* *}}$ \\
\hline
\end{tabular}

Values are expressed as mean \pm S.E.M., $n=6, \mathrm{DEXA}=$ dexamethasone $1 \mathrm{mg} / \mathrm{kg}, \mathrm{i} . \mathrm{m}$.,

$\mathrm{PIO}=$ Pioglitazone $2 \mathrm{mg} / \mathrm{kg}$, p.o., ER= Embelia ribes , 100, 200mg/kg, p.o.

$\mathrm{a}^{* *} p<0.01$ when compared with normal control or normal + insulin.

$\mathrm{b}^{* *} p<0.01$ when compared with DEXA-control.

$c^{* *} p<0.01$ when compared with DEXA+ insulin group

\section{RESULTS}

Effects of ER on plasma glucose, serum triglyceride, body weight, plasma insulin and Homa -IR index:

In DEXA-control group there was significant increase in plasma glucose level $(p<0.01)$ and serum triglyceride level $(p<0.01)$ when compared with normal control. All mice treated with DEXA and ER showed significant decrease $(p<0.01)$ in the levels of plasma glucose and serum triglyceride when compared with DEXAcontrol. The mice treated with DEXA and Pioglitazone showed significant decrease in plasma glucose level $(p<0.01)$ and serum triglyceride level $(p<0.01)$ when compared with DEXA-control.ER at the dose of $100 \mathrm{mg} / \mathrm{kg}$, p.o. showed marginal hypoglycemia $(p<0.05)$ when compared with normal control. Significant reduction $(p<0.01)$ in body weight was observed in DEXA-control group when compared with normal control. ER and Pioglitazone treatment significantly inhibited the dexamethasone induced decrease in body weight $(p<0.01)$ when compared DEXA-control. Dexamethasone administration for 21 days in mice leads to development of insulin resistance as indicated by significant increase in HOMA-IR index $(\mathrm{P}<0.01)$ when compared to control. 


\section{Effects of ER on MDA, GSH, SOD and CAT levels}

In DEXA-control group there was increase in the levels of MDA), GSH ( $p<0.01)$ when compared with normal control, treatment with ER significantly prevented this rise $(p<0.01)$. DEXA-control group showed significant decrease $(p<0.05)$. SOD and CAT when compared with normal control, whereas significant increase $\mathrm{b}(p<0.01)$ in the levels of these enzymes was observed in the ER treated groups when compared with DEXA-control group.

\subsection{Effect of ER on glucose uptake in mice isolated hemidiaphragm}

Hemidiaphragm of the mice treated with dexamethasone showed significant decrease $(p<$ 0.01) in glucose uptake when compared with normal control. Pioglitazone did not show any significant increase in glucose uptake by mice isolated hemidiaphragm. TG at higher doses i.e. $100,200 \mathrm{mg} / \mathrm{kg}$, p.o. showed significant increase $(p<0.01)$ in glucose uptake when compared with DEXA-control. In insulin assisted glucose uptake, Pioglitazone showed significant increase $(p<0.01)$ in glucose uptake when compared with DEXA+ insulin group. Higher doses ER $100,200 \mathrm{mg} / \mathrm{kg}$, p.o. along with insulin showed significant increase $(p<0.01)$ in glucose uptake when compared with DEXA+ insulin group.

\section{DISCUSSION AND CONCLUSION}

In the present study, dexamethasone administration resulted in significant increase in blood glucose and triglyceride level. ER showed dose dependent decrease in elevated plasma glucose and triglyceride levels caused by dexamethasone, Embelin, one of the chemical constituents of Embelia ribes was reported to possess glucocorticoid antagonistic action. The effect of ER on the plasma glucose level and triglyceride level may be due to the glucocorticoid antagonism and the presence of other chemical constituents like alkaloids and tannins which are reported to have antihyperglycemic action ER showed significant increase in insulin assisted glucose uptake, which indicates that there was increase in the insulin sensitivity. (17) Glucocorticoid treatment is known to induce insulin resistance and catabolic states in rats. (18) Pharmacological doses of glucocorticoids induce $o b$ gene expression in rat adipocyte tissues within $24 \mathrm{~h}$ which is followed by complex metabolic changes like hyperleptinemia, resulting in decrease in food consumption, reduction in body weight with enhanced blood glucose and triglyceride levels (19) As expected, in the present study, dexamethasone group showed reduction in body weight, while TG and Pioglitazone treatment inhibited dexamethasoneinduced reduction in body weight and showed marginal increase in body weight. The effect of TG on the body weight may be attributed to the increase in the sensitivity to insulin and the subsequent increase in the glucose uptake. Oxidative stress can be generated by hyperglycemia and for a long time it has been accused to cause insulin resistance. Insulin resistance induces release of cytokines like TNFalpha, IL-8 which leads to development of oxidative stress in liver by reducing the mitochondrial levels of $\mathrm{Cu} / \mathrm{Zn} \mathrm{SOD}$, glutathione and producing $\mathrm{H}_{2} \mathrm{O}_{2}$ radicals and leads to increase in lipid peroxidation. Mitochondria are significant source for generation of superoxide radicals. (20) Insulin resistance is associated with increase in fat accumulation and mitochondrial oxidative stress. In present study, TG showed significant increase in the concentration of various antioxidant enzymes, which could be beneficial in countering, the hyperglycemia induced oxidative stress. Ethanolic extract of Embelia ribes contains tannins, alkaloids and saponins. Tannins and saponins play a major role in reducing oxidative stress associated with diabetes probably by scavenging the free radicals and preventing the depletion of endogenous antioxidant. (21) Thus the results obtained in the present investigation indicate that Embelia ribes may prove to be useful in insulin resistance owing to its antioxidant activity and ability to increase the glucose uptake.

\section{ACKNOWLEDGEMENT}

The authors are thankful to Dr F.V. Manvi Principal and Prof A.D. Taranalli Vice Principal K.L.E's College of pharmacy Belgaum, for providing necessary facilities to carry out research work. 


\section{CONFLICTS OF INTEREST}

The author declares that there are no conflicts of interest.

\section{REFERENCES}

1. Ghaisas M et al., Effect of Tectona grandis Linn. On Dexamethasone- induced insulin resistance in mice." Journal of Ethnopharmacology, (2009-under press).

2. O'Rahilly, S. Science, medicine, and the future. Noninsulin dependent diabetes mellitus: the gathering storm. BMJ. 1997; 314:955-59.

3. Warram JH, Martin BC, Krolewski AS, Soeldner JS, and Kahn CR. Slow glucose removal rate and hyperinsulinemia precede the development of type II diabetes in the offspring of diabetic patients. Ann. Intern. Med. 1990; 113:909-15.

4. Lillioja, S., et al. Impaired glucose tolerance as a disorder of insulinaction". Longitudinal and crosssectional studies in Pima Indians. N. Engl J. Med. 318:1217-25.

5. DeFronzo RA. 1988. The triumvirate: beta-cell, muscle, liver: a collusio responsible for NIDDM. Diabetes. 1988; 37:667-87.

6. Gholap and A. Kar, "Gymnemic acids from Gymnema sylvestre potentially regulates Dexamethasone induced hyperglycemia in mice" pharmaceutical biology 2005; 43: p.192-95.

7. Vaidya Arya MR. Sthaulya Cikitsa (Treatment of obesity) In: A Compendium of Ayurvedic Medicine, Principles and Practice, 1999; pp. 335- 339. Delhi.

8. Tripathi S N, "Screening of hypoglycemic action in certain indigenous Drugs" J Indian Med Yoga Homeopath, 1979; 14:159.

9. Bhandari U et. Al; "Antihyperglycemic activity of aqueous extract of Embelia ribes burm in streptozocin induced diabetic rats" Indian journal of exp. Biology august 2008; 46: pp.607-6.

10. Ohkawa, M., Ohishi, N., and Yagi, K. (1979) Assay for lipid peroxides in animal tissue by thiobarbituric acid reaction. Anal. Biochem., 95, 351-58.

11. Chatterjee NA. IB: Assay of superoxide dismutase activity in animal tissue. $J$ Biosci 1988, 13:305-15.

12. Sinha AK. Colorimetric assay of catalase. Anal Biochem 1972, 47:389-394

13.Ellman GL. (1959) Tissue sulfhydryl groups. Arch. Biochem. Biophys. 82, 70-7.

14. Chattopadhyay RR, Sarkar SK, Ganguli S, Banerjee RN, Basu TK. 1992. Effect of extract of leaves of Vinca rosea Linn on glucose utilization and glycogen. Indian Journal of Physiology and Pharmacology 36, 137-38.

15. Ghosh R, Sharatchandra K, Rita S, Thokchom IS. 2004. Hypoglycemic activity of Ficus hispida (bark) in normal and diabetic albino rats. Indian Journal of Pharmacology36, 222-25.

16. Sabu MC, Subburaju T. 2002. Effect of Cassia auriculata Linn. on serum glucose level, glucose utilization by isolated rat hemidiaphragm. Journal of Ethno pharmacology 80, 203-06.

17. Krishna S \& Verma KS. Embelia ribes, Indian forest Bulletin N.S No.102(1941)
18. Harber RS, Weinstein SP. 1992. Role of glucose transporter in glucocorticoid induced insulin resistance GLUT4 isoform in rat skeletal muscle is not decreased by dexamethasone. Diabetes 41, 728-35.

19. Kim DS, Kim TW, Park IK, Kang JS. Om, A.S., 2002. Effect of chromium picolinate supplementation on insulin sensitivity, serum lipid, and body weight in dexamethasone-treated rats. Metabolism 51, 589-94.

20. Marfella R, Quagliaro L, Nappo F, Ceriello A, Giugliano D. 2001. Acute hyperglycemia induces an oxidative stress in healthy subjects. Journal of Clinical Investigation 108, 635-36.

21. Bruneton J. 1999. Pharmacognosy. In: Phytochemistry Medicinal Plants. Lavoisier Publishers, London, pp. 386-87. 